\title{
Assessment of Livelihood Vulnerability to Drought: A Case Study in Dak Nong Province, Vietnam
}

\author{
Nguyen Thi Thanh Thao ${ }^{1,2} \cdot$ Dao Nguyen Khoi ${ }^{3,4} \cdot$ Tran Thanh Xuan ${ }^{5}$. \\ Bernard Tychon ${ }^{1}$
}

Published online: 11 September 2019

(C) The Author(s) 2019

\begin{abstract}
In recent years, droughts have strongly affected the Central Highlands of Vietnam and have resulted in crop damage, yield decline, and serious water shortage. This study investigated the livelihood vulnerability of five communities of farmers who are exposed to droughts in one of the more vulnerable regions of Vietnam-Dak Nong Province. A survey of 250 households was conducted in the five communities to collect data on the region's sociodemographic profile, livelihood systems, social networks, health status, food and water security, drought conditions, and climate variability. Data were aggregated using a livelihood vulnerability index and the IPCC vulnerability index. The survey results indicate that Quang Phu community is the most vulnerable of the study's communities, followed by Nam N'dir, Dak Nang, Duc Xuyen, and Dak D'ro in descending order of vulnerability. Water availability and livelihood strategies are the most important variables in determining the vulnerability of the five surveyed communities. In order to reduce vulnerability to droughts, water management practices and livelihood
\end{abstract}

Dao Nguyen Khoi

dnkhoi86@gmail.com; dnkhoi@hcmus.edu.vn

1 Université de Liège, 6700 Arlon, Belgium

2 Institute for Environmental Science, Engineering, and Management, Industrial University of Ho Chi Minh City, Ho Chi Minh City, Vietnam

3 Institute of Research and Development, Duy Tan University, Da Nang, Vietnam

4 Faculty of Environment, University of Science, Vietnam National University Ho Chi Minh City, Ho Chi Minh City, Vietnam

5 NTT Institute of Hi-Technology, Nguyen Tat Thanh University, Ho Chi Minh City, Vietnam diversification in farming and nonfarming activities are recommended for the study area.

Keywords Agricultural drought · Livelihood vulnerability $\cdot$ Vietnam $\cdot$ Vulnerability indicators

\section{Introduction}

Drought is a recurrent natural hazard that has negative impacts on water resources and the socioeconomic situation of affected communities. Drought results from a considerable water deficit due to climatic factors such as decreases in rainfall (Mohmmed et al. 2018) or human factors, for example, land-use change (Keesstra 2007). Basically, drought is categorized into four major typesmeteorological, hydrological, agricultural, and socioeconomic droughts - depending on its impacts (Thilakarathne and Sridhar 2017). Recently, drought frequency and severity have significantly increased due to climate change (IPCC 2013a). This forcing variable generates large challenges for the socioeconomic development of developing countries, especially in the agricultural sector. Panthi et al. (2016) have indicated that people whose livelihood relies mostly on agricultural activities are particularly vulnerable in the developing countries. Therefore, studies of the impacts of climate change and natural hazards are necessary to improve knowledge about people's vulnerability and to help decision makers plan for and implement climate change adaptation and disaster risk reduction. According to the Intergovernmental Panel on Climate Change (IPCC 2001), vulnerability is defined as the extent to which geophysical, biological, and societal aspects are disposed to, or at risk of, and are unable to deal with the adverse effect of climate change and variability. 
Vulnerability assessment depicts a varied set of approaches used to systematically integrate and consider interactions between humans and their environmental surroundings, including physical and social aspects (Hahn et al. 2009).

In recent years, vulnerability assessment in the context of climate change and natural hazard-induced disasters has gained more attention from scientists. Approaches to vulnerability assessment include historical narrative, comparative analysis, statistical analysis, indicator-based methods, and agent-base modeling. Among these methods, the indicator-based method is widely used to assess vulnerability to climate change and natural hazard-induced disasters (Pandey and Jha 2012; Salik et al. 2015; Mohmmed et al. 2018). In the past decade, the livelihood vulnerability index (LVI) has been a useful and popular tool in assessing farmers' vulnerability to climate change and disasters around the world (Addisu Legese et al. 2016; Panthi et al. 2016; Adu et al. 2018; Oo et al. 2018; Williams et al. 2018). Computed and improved by Hahn et al. (2009) based on the Intergovernmental Panel on Climate Change (IPCC) definition of vulnerability, the LVI approach consists of various variables apprehending the level of smallholder farmers' exposure, sensitivity, and adaptive capacity to natural hazard-induced disasters (for example, droughts and floods) and climate change. The livelihood vulnerability index provides measures to observe likely vulnerability over time and space and to identify the processes that contribute to vulnerability, prioritize strategies for its reduction, and assess the efficiency of these strategies in different social and ecological environments (Shah et al. 2013). Panthi et al. (2016) indicated that the impact of climate change and disasters varies from area to area and that vulnerability assessment, to be reliable, must be investigated at a regional scale.

Vietnam, a tropical and developing country in Southeast Asia, is identified as one of the most vulnerable hotspots affected by climate change and natural hazard-induced disasters such as droughts and floods (IPCC 2013b; IMHEN and UNDP 2015). In the past two decades, Vietnam suffered approximately 216 natural hazard-induced disasters that caused a loss of approximately $0.55 \%$ of the gross domestic product (GDP) per year (Eckstein et al. 2017). In 2015-2016, Vietnam, especially in the Central Highlands, has faced the most severe prolonged drought in the past 90 years, which caused severe damage to agricultural production and farmer income (UNDP 2016). The Central Highland area is an important place for Vietnam's economy because this region is the biggest producer of coffee beans in Vietnam, and Vietnam is the world's second largest exporter of coffee. A recent study conducted by Sam et al. (2018) stated that the droughts in the Central Highlands are becoming increasingly more severe and prolonged, and maintained that this trend will continue into the near future. This will cause serious impacts on agriculture and the livelihood of this region's inhabitants. Poor farming communities are identified as the principal victim of climate change and natural hazard-induced disasters in developing countries, because they have insufficient adaptive capacity (IPCC 2007). However, the livelihood vulnerability of farmers to drought is not well reported in Vietnam, especially in the Central Highlands. A lack of knowledge of drought impacts on farmers' livelihood is an obstacle to the determination of suitable livelihood strategies that may increase farmers' welfare in the context of drought.

The objective of the present study is to assess the livelihood vulnerability of farmers to droughts in the Krong No District, Dak Nong Province in the Central Highlands of Vietnam. Five communities in the district, namely Quang Phu, Nam N'dir, Dak Nang, Duc Xuyen, and Dak D'ro, were selected for the investigation because they were the most vulnerable areas affected by the historical drought in 2015-2016 (FAO 2016). The results of this study are expected to help local governments find drought adaptations to enhance farmers' adaptive capacity in the study area.

\section{Study Area}

The Krong No District is located in the Central Highlands of Vietnam (Fig. 1). The district is positioned between latitudes $12^{\circ} 15^{\prime}-12^{\circ} 30^{\prime} \mathrm{N}$ and longitudes $107^{\circ} 45^{\prime}-$ $108^{\circ} 05^{\prime} \mathrm{E}$. This district has an average altitude higher than $2,000 \mathrm{~m}$ with an area of $813 \mathrm{~km}^{2}$ and its population was about 70,604 people in 2014 (Dak Nong Statistical Office 2015). Krong No District experiences a tropical monsoonal climate with distinct dry and wet seasons. Rainfall is highly seasonal, is concentrated in the monsoon season, and lasts from April or May to November. Average annual temperature is around $25^{\circ} \mathrm{C}$. The months of July, August, and September have the largest precipitation, up to $320 \mathrm{~mm}$. In the dry season, average temperature is around $20^{\circ} \mathrm{C}$ and average precipitation is about $4-5 \mathrm{~mm}$ in January and February. Average annual relative humidity is approximately $76 \%$ and the highest value is $89 \%$ in August.

\section{Methodology}

In this study, the LVI and VI-IPCC were used to evaluate the livelihood vulnerability of households to drought in the Krong No District. The two vulnerability indices were selected for this study because they have been widely used in studies on assessing the vulnerability to climate change and disasters (Panthi et al. 2016; Adu et al. 2018; Oo et al. 


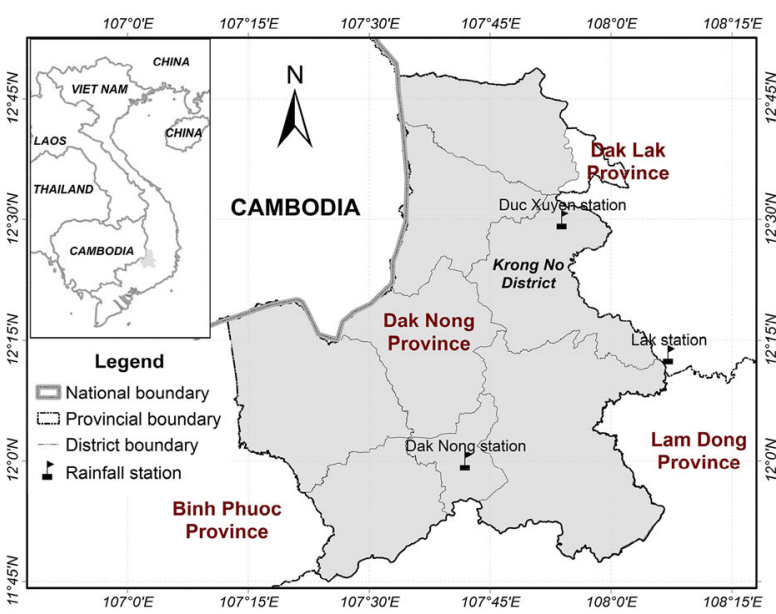

(a) Dak Nong Province (grey area)

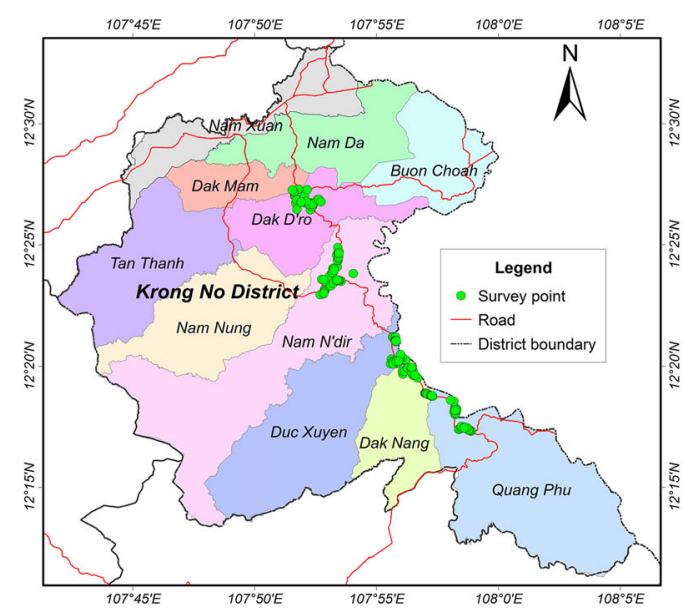

(b) Krong No District

Fig. 1 Location of the a Dak Nong Province and b Krong No District

2018). In the following subsections, we provide the detailed methods of LVI and VI-IPCC used in this study.

\subsection{Livelihood Vulnerability Index}

According to Hahn et al. (2009), the LVI includes seven major components: sociodemographic profile (SDP); livelihood strategies (LS); social networks (SN); health $(\mathrm{H})$; food $(\mathrm{F})$; water $(\mathrm{W})$; and natural hazard-induced disasters and climate variability. In this study, the LVI was calculated based on these seven major components, and each component contained a different number of subcomponents (Table 1) based on available data collected through a survey of households affected by the droughts of 2015-2016 in the study area. As subcomponents were evaluated on diverse scales, they were first standardized. Standardization was based on the Human Development Index (HDI) of UNDP (2007).

Index $_{c}=\frac{S_{c}-S_{\min }}{S_{\max }-S_{\min }}$

where $S_{c}$ is the original value of the subcomponent for community $c, S_{\min }$ and $S_{\max }$ are minimum and maximum values reflecting low and high vulnerability of this subcomponent.

After standardizing subcomponents, the major component index was calculated by the following equation:

$M_{j c}=\frac{\sum_{i=1}^{n} \text { index } S_{c}}{n}$

where $n$ is the number of sub-components in each major components and $M_{j c}$ is the value of major component $j$ for community $c$. The LVI for a community was calculated using the following equation:
$L V I=\frac{\sum_{i=1}^{n} w_{M i} M_{i c}}{\sum_{i=1}^{n} w_{M i}}$

where $w_{M i}$ is the weight of each major component, which was estimated by the number of subcomponents that make up each major component.

After calculating the major components and LVI, a radar chart was used to compare the vulnerability level of each major component for each community. The livelihood vulnerability index was scaled in the range from 0 (least vulnerable) to 1 (most vulnerable).

\subsection{IPCC Vulnerability Index}

This study uses VI-IPCC to assess livelihood vulnerability based on the IPCC approach. VI-IPCC highlights three major components-exposure, adaptive capacity, and sensitivity. Drought is framed under "exposure," water, food, and health sectors under "sensitivity," and sociodemographic profile, livelihood strategy, and social network under "adaptive capacity".

Exposure is measured by using rainfall data from three rain gauges located in the study area. Sensitivity is measured by assessing the current state of Dak Nong Province's food and water security and health status. Adaptive capacity is quantified by using the sociodemographic profile data, types of livelihood strategies, and existing social networks in the study area. The same subcomponents used for the LVI index as well as Eqs. 1 and 2 were employed to calculate the VI-IPCC index. The VI-IPCC index is calculated as follows.

VI-IPCC $=($ Exposure - Adaptive capacity $) \times$ Sensitivity 
Table 1 Major components and subcomponents of the livelihood vulnerability index (LVI) developed for five communities in the Krong No District in Dak Nong Province of Vietnam

\begin{tabular}{|c|c|c|c|}
\hline Major components & Subcomponents & Unit & $\begin{array}{l}\text { Explanation of subcomponents relative } \\
\text { to LVI }\end{array}$ \\
\hline \multirow[t]{5}{*}{$\begin{array}{l}\text { Sociodemographic } \\
\text { profile (SDP) }\end{array}$} & SDP1-Ratio of dependent people. & - & $\begin{array}{l}\text { Higher value reflects less capacity to } \\
\text { adapt }\end{array}$ \\
\hline & SDP2_Percentage of female-headed households. & $\%$ & $\begin{array}{l}\text { Higher value reflects less capacity to } \\
\text { adapt }\end{array}$ \\
\hline & & & $\begin{array}{l}\text { Women typically have less adaptive } \\
\text { capacity }\end{array}$ \\
\hline & $\begin{array}{l}\text { SDP3-Percentage of household heads who have not } \\
\text { attended school }\end{array}$ & $\%$ & $\begin{array}{l}\text { Higher value reflects less capacity to } \\
\text { adapt }\end{array}$ \\
\hline & & & $\begin{array}{l}\text { Education makes people more aware and } \\
\text { able to adjust to change in } \\
\text { environmental conditions }\end{array}$ \\
\hline \multirow[t]{6}{*}{$\begin{array}{l}\text { Livelihood } \\
\quad \text { strategies (LS) }\end{array}$} & $\begin{array}{l}\text { LS1-Livelihood diversification index, which was } \\
\text { constructed as the inverse of the number of livelihood } \\
\text { activities of households }+1 \text { ) }\end{array}$ & - & $\begin{array}{l}\text { Higher value reflects more capacity to } \\
\text { adapt }\end{array}$ \\
\hline & & & $\begin{array}{l}\text { Income diversification increases } \\
\text { adaptive capacity }\end{array}$ \\
\hline & $\begin{array}{l}\text { LS2_-Percentage of households depending only on } \\
\text { agriculture as a source of income }\end{array}$ & $\%$ & $\begin{array}{l}\text { Higher value reflects less capacity to } \\
\text { adapt }\end{array}$ \\
\hline & & & $\begin{array}{l}\text { Households depending only on } \\
\text { agriculture are more vulnerable }\end{array}$ \\
\hline & $\begin{array}{l}\text { LS3-Agricultural livelihood diversification index, which } \\
\text { was constructed as the inverse of the number of crops } \\
\text { cultivated by a household }+1 \text { ) }\end{array}$ & - & $\begin{array}{l}\text { Higher value reflects more capacity to } \\
\text { adapt }\end{array}$ \\
\hline & & & $\begin{array}{l}\text { Diverse crops reduce the risk of major } \\
\text { losses }\end{array}$ \\
\hline \multirow[t]{4}{*}{ Food $(F)$} & $\begin{array}{l}\text { F1-Percentage of households depending only on their } \\
\text { farming products as a source for food }\end{array}$ & $\%$ & Higher value indicates vulnerable \\
\hline & & & Limited source for food \\
\hline & F2-Monthly living expense & $\begin{array}{l}1000 \\
\mathrm{VND} / \mathrm{month}^{\mathrm{a}}\end{array}$ & Higher value indicates less vulnerable \\
\hline & $\begin{array}{l}\text { F3-Percentage of households struggling for food. } \\
\text { Proportion of households reported that they had at least } \\
\text { one month struggling for food }\end{array}$ & $\%$ & Higher value indicates more vulnerable \\
\hline \multirow[t]{6}{*}{$\begin{array}{l}\text { Social Network } \\
\quad(\mathrm{SN})\end{array}$} & $\begin{array}{l}\text { SN1_Percentage of households not having access to } \\
\text { communication media (TV/radio, telephone) }\end{array}$ & $\%$ & Higher value indicates more vulnerable \\
\hline & & & $\begin{array}{l}\text { Communication media makes people } \\
\text { aware of hazard occurrence and } \\
\text { having better preparation }\end{array}$ \\
\hline & $\begin{array}{l}\text { SN2-Percentage of households not having access to local } \\
\text { government service }\end{array}$ & $\%$ & Higher value indicates more vulnerable \\
\hline & & & $\begin{array}{l}\text { These services strengthen adaptive } \\
\text { capacity }\end{array}$ \\
\hline & $\begin{array}{l}\text { SN3-Percentage of households not having access to funds } \\
\text { from government or other organizations }\end{array}$ & $\%$ & Higher value indicates more vulnerable \\
\hline & & & $\begin{array}{l}\text { Funds sources strengthen adaptive } \\
\text { capacity }\end{array}$ \\
\hline \multirow[t]{4}{*}{ Health $(\mathrm{H})$} & H1-Average distance to a health facility & $\mathrm{km}$ & Higher value indicates more vulnerable \\
\hline & $\begin{array}{l}\text { H2-Percentage of households with family member with } \\
\text { chronic illness }\end{array}$ & $\%$ & Higher value indicates more vulnerable \\
\hline & & & $\begin{array}{l}\text { People with chronic illness are more } \\
\text { sensitive }\end{array}$ \\
\hline & $\begin{array}{l}\text { H3-Percentage of households not participating in health } \\
\text { insurance }\end{array}$ & $\%$ & Higher value indicates more vulnerable \\
\hline
\end{tabular}


Table 1 continued

\begin{tabular}{|c|c|c|c|}
\hline Major components & Subcomponents & Unit & $\begin{array}{l}\text { Explanation of subcomponents relative } \\
\text { to LVI }\end{array}$ \\
\hline \multirow[t]{4}{*}{ Water (W) } & $\begin{array}{l}\text { W1-Percentage of households using natural water sources } \\
\text { from well or stream }\end{array}$ & $\%$ & Higher value indicates more vulnerable \\
\hline & $\begin{array}{l}\text { W2-Percentage of households not having stable water from } \\
\text { a water treatment plant }\end{array}$ & $\%$ & Higher value indicates more vulnerable \\
\hline & & & $\begin{array}{l}\text { Family with unstable water supply is } \\
\text { more sensitive }\end{array}$ \\
\hline & W3-Storage water volume of households & $\mathrm{m}^{3}$ & Higher value indicates less vulnerable. \\
\hline \multirow[t]{3}{*}{ Drought (D) } & $\begin{array}{l}\text { D1-Frequency of drought (6-month Standardized } \\
\text { Precipitation Index (SPI6)) }\end{array}$ & $\%$ & Higher value reflects more exposure \\
\hline & D2-Mean standard deviation of monthly precipitation & - & $\begin{array}{l}\text { Higher variability implies higher } \\
\text { exposure }\end{array}$ \\
\hline & $\begin{array}{l}\text { D3-Mean standard deviation of monthly maximum } \\
\text { temperature }\end{array}$ & - & $\begin{array}{l}\text { Higher variability implies higher } \\
\text { exposure }\end{array}$ \\
\hline
\end{tabular}

${ }^{\mathrm{a}} 1 \mathrm{USD}=23.25$ VND (exchange rate on 2 September 2019); SPI6 = 6-month standardized precipitation index

The VI-IPCC index values range from -1 (least vulnerable) to +1 (most vulnerable). IPCC-defined contributing factors (exposure, adaptive capacity, and sensitivity) are calculated as:

$C F_{c}=\frac{\sum_{i=1}^{n} w_{M i} M_{c i}}{\sum_{i=1}^{n} w_{M i}}$

where $C F_{c}$ is an IPCC-defined contributing factor for community $c, w_{M i}$ is the weight of each major component determining factor, $M_{c i}$ is the major component for community $c$ indexed $i$, and $n$ is the number of major components in each contributing factor.

After calculating contributing factors (exposure, adaptive capacity, and sensitivity) and VI-IPCC, these results are described by using vulnerability triangle diagrams to compare two or more study areas. Each vertex of a triangle shows each contributing factor.

\subsection{Data Collection}

This study uses data from both primary and secondary sources. Secondary data on monthly precipitation measured at three rain gauges (the Lak, Duc Xuyen, and Dak Nong stations) (Fig. 1a) were collected. These data were collected for the period 1981-2016 and obtained from the Hydro-Meteorological Data Center of Vietnam (HMDC). In order to estimate drought frequency, the standardized precipitation index (SPI) was used based on the monthly precipitation data. The SPI is calculated based on the probability distribution of monthly precipitation using gamma density function for specified monthly time scales
(1, 3, 6, 12, or 24 months). The SPI for a 6-month time scale was selected to estimate drought frequency because it is suitable for describing seasonal meteorological drought (Spinoni et al. 2014). The procedure for SPI calculation can be found in McKee et al. (1993).

Primary data were gathered from our household questionnaire survey. A structured questionnaire was designed in relation to LVI's components and subcomponents. The questionnaire contained socioeconomic, demographic, and livelihood information at community and district levels in the Krong No District. In addition, it contained questions related to drought, climate change perceptions, adaptive solutions, and interventions that each stakeholder is able to support and apply to reduce the negative impacts of drought in each community. The sample size was calculated at a $95 \%$ confidence level, precision of $\pm 10 \%$ at an assumed coverage of $50 \%$ based on the probability proportional to size method. A household survey was carried out with 250 households who were selected at random in five communities of the Krong No District in April 2016, and 50 households in each community-Quang Phu, Nam N'dir, Dak Nang, Duc Xuyen, Dak D'ro-respectively were surveyed. Households were randomly selected from the household lists of all communities. The survey was carried out by six undergraduate-level interviewers who were trained. Household heads or other experienced members of the selected households were considered for the survey. Each interview lasted approximately $30 \mathrm{~min}$ and was conducted in the Vietnamese language. The local people, including non-Vietnamese minority groups, have used Vietnamese language in daily communication. Data 
were inputted, checked, and analyzed using MS Excel version 16.0. The main survey objective was to collect information on indicators listed in Table 1.

\section{Results and Discussion}

The collected information of the survey questionnaires is summarized in Table 2, which includes the result of indices in five communities, and maximum and minimum values. Table 3 shows the result of LVI of the five communities and Krong No District after standardizing and aggregating into seven main components, including Sociodemographic profile (SDP), Livelihood strategies (LS), Food (F), Water $(\mathrm{W})$, Health $(\mathrm{H})$, Social networks (SN), and Drought (D). Table 4 is the result of VI-IPCC for the Krong No District, after aggregating the seven main components into three contributing factors, namely Adaptive capacity (Sociodemographic profile, Livelihood strategies, Social networks), Sensitivity (Health, Food, Water), and Exposure (Drought).

The results indicate that the vulnerability of the Krong No District (average of five communities) estimated by the LVI and VI-IPCC indices is moderate based on the vulnerability scales of 0 to 1 for LVI and -1 to 1 for VIIPCC. Specifically, the values of LVI and VI-IPCC are
0.444 and -0.096 . Considering the vulnerability of the five communities, the LVI and VI-IPCC values indicated that households of the Quang Phu community are the most vulnerable, followed by Nam N'dir, Dak Nang, Duc Xuyen, and Dak D'ro communities (Tables 3, 4).

\subsection{Drought in the Krong No District}

Using the Thiessen polygon method to analyze the station rainfall and drought spatial correlation, the two rain gauges whose rainfall is closely correlated with droughts in the study region are the Duc Xuyen and Lak stations. The Duc Xuyen station rainfall in particular is correlated with droughts in the whole Dak D'ro community, most of Nam N'dir and Duc Xuyen communities, and a part of Dak Nang community. The Lak station rainfall has a close correlation with droughts in the Quang Phu community and the remaining part of the Dak Nang and Duc Xuyen communities (Fig. 1). Besides, Fig. 2 and Table 5 specify the drought levels of the three rain gauges. The associated areas of Duc Xuyen station tend to be more heavily affected by droughts than the other areas. Quang Phu, whose rainfall is closely related to the Lak station, is the least drought-affected community compared to the other communities. In general, drought frequency of Krong No

Table 2 The result of values of LVI subcomponents for the five communities in the Krong No District in Dak Nong Province, Vietnam

\begin{tabular}{|c|c|c|c|c|c|c|c|c|}
\hline Indices & Unit & Quang Phu & Dak D’ro & Dak Nang & Nam N'dir & Duc Xuyen & $\max$ & $\min$ \\
\hline SDP1 & - & 0.32 & 0.21 & 0.26 & 0.36 & 0.29 & 1 & 0 \\
\hline SDP2 & $\%$ & 13.95 & 2.44 & 4.88 & 21.43 & 7.55 & 100 & 0 \\
\hline SDP3 & $\%$ & 28.57 & 10.26 & 0.00 & 16.67 & 2.70 & 100 & 0 \\
\hline LS1 & - & 0.47 & 0.39 & 0.43 & 0.41 & 0.42 & 0.50 & 0.25 \\
\hline LS2 & $\%$ & 88.37 & 80.49 & 87.80 & 78.57 & 73.58 & 100 & 0 \\
\hline LS3 & - & 0.32 & 0.30 & 0.32 & 0.32 & 0.31 & 0.500 & 0.143 \\
\hline F1 & $\%$ & 30.23 & 34.15 & 29.27 & 33.93 & 16.98 & 100 & 0 \\
\hline $\mathrm{F} 2$ & $1000 \mathrm{VND} / \mathrm{month}$ & 1431.63 & 1821.46 & 1790.49 & 1464.46 & 2288.87 & 6000 & 0 \\
\hline F3 & $\%$ & 30.23 & 36.59 & 14.63 & 32.14 & 32.08 & 100 & 0 \\
\hline W1 & $\%$ & 100.00 & 56.10 & 100.00 & 98.21 & 37.74 & 100 & 0 \\
\hline W2 & $\%$ & 76.74 & 51.22 & 75.61 & 73.21 & 64.15 & 100 & 0 \\
\hline W3 & $\mathrm{m}^{3}$ & 2.01 & 1.33 & 1.03 & 1.99 & 0.87 & 10 & 0 \\
\hline H1 & $\mathrm{m}$ & 1582.50 & $13,98.78$ & 1235.90 & 1607.27 & 1416.98 & 5000 & 10 \\
\hline $\mathrm{H} 2$ & $\%$ & 65.12 & 43.90 & 36.59 & 46.43 & 50.94 & 100 & 0 \\
\hline H3 & $\%$ & 37.21 & 4.88 & 29.27 & 35.71 & 20.75 & 100 & 0 \\
\hline SN1 & $\%$ & 6.98 & 4.88 & 7.32 & 10.71 & 1.89 & 100 & 0 \\
\hline $\mathrm{SN} 2$ & $\%$ & 65.12 & 48.78 & 56.10 & 80.36 & 71.70 & 100 & 0 \\
\hline SN3 & $\%$ & 53.49 & 26.83 & 14.63 & 46.43 & 33.96 & 100 & 0 \\
\hline D1 & $\%$ & 16.06 & 16.37 & 16.58 & 16.57 & 16.86 & 100 & 0 \\
\hline D2 & $\mathrm{mm}$ & 88.25 & 81.64 & 73.16 & 72.38 & 71.06 & 168.90 & 5.68 \\
\hline D3 & Celsius & 2.03 & 2.03 & 2.03 & 2.03 & 2.03 & 2.29 & 1.75 \\
\hline
\end{tabular}

SDP = Sociodemographic profile; LS = Livelihood strategy; F = Food; W = Water; H = Health; SN = Social networks; D = Drought 
Table 3 LVI components calculation for five communities in Krong No District in Dak Nong Province, Vietnam

\begin{tabular}{lllllll}
\hline & Quang Phu & Dak D'ro & Dak Nang & Nam N'dir & Duc Xuyen & Krong No District \\
\hline SDP & 0.248 & 0.113 & 0.103 & 0.246 & 0.130 & 0.168 \\
LS & 0.748 & 0.603 & 0.692 & 0.637 & 0.624 & 0.661 \\
F & 0.455 & 0.468 & 0.380 & 0.472 & 0.370 & 0.429 \\
W & 0.855 & 0.647 & 0.884 & 0.839 & 0.644 & 0.774 \\
H & 0.446 & 0.255 & 0.301 & 0.381 & 0.333 & 0.343 \\
SN & 0.419 & 0.268 & 0.260 & 0.458 & 0.358 & 0.353 \\
D & 0.399 & 0.387 & 0.370 & 0.369 & 0.367 & 0.378 \\
LVI & 0.510 & 0.392 & 0.427 & 0.486 & 0.404 & 0.444 \\
\hline
\end{tabular}

SDP = Sociodemographic profile; LS = Livelihood strategy; F = Food; W = Water; H = Health; SN = Social networks; D = Drought; LVI $=$ Livelihood vulnerability index

Table 4 VI-IPCC contributing factors calculation for five communities and Krong No District in Dak Nong Province, Vietnam

\begin{tabular}{lcccccc}
\hline & Quang Phu & Dak D'ro & Dak Nang & Nam N'dir & Duc Xuyen & Krong No District \\
\hline Adaptive capacity (AC) & 0.496 & 0.631 & 0.607 & 0.505 & 0.586 & 0.565 \\
Sensitivity (S) & 0.586 & 0.457 & 0.522 & 0.564 & 0.449 & 0.515 \\
Exposure (E) & 0.399 & 0.387 & 0.370 & 0.369 & 0.367 & 0.378 \\
VI-IPCC & -0.057 & -0.112 & -0.124 & -0.077 & -0.099 & -0.096 \\
\hline
\end{tabular}

The VI-IPCC (Vulnerability Index-Intergovernmental Panel on Climate Change) is scaled and ranges from - 1 (least vulnerable) to +1 (most vulnerable)

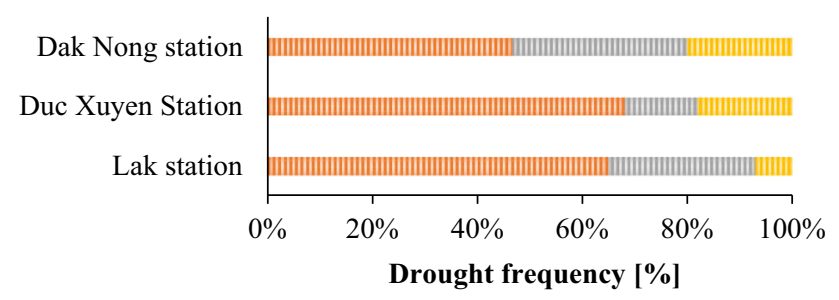

피 Moderate drought $\quad$ |II Severe drought $\quad$ ||I Extreme drought

Fig. 2 Drought frequency at the three rain gauges in the Krong No District of Dak Nong Province, Vietnam

District is about $16 \%$ in which moderate drought occupies more than $66 \%$ of the area, severe drought occupies about $20 \%$, and extreme drought afflicts about $14 \%$. This suggests that drought in Krong No is a great threat that should be taken into special consideration, especially in those regions measured by the Duc Xuyen station.

Since the income of households is intensely dependent on farming, the condition of food security is frail in the study area. Nearly $30 \%$ of Krong No Districts households struggle with food availability; and, according to our survey, this period of difficulty falls in the months when the crop has not yet been harvested (from January to May, with a peak in March, Fig. 3). It is noteworthy that the period of food shortage also coincides with the time when households lack water for domestic use as well as irrigation (this deficit period also falls between January and May, peaks in March, Fig. 3). Once drought seriously occurs, it severely

Table 5 The result of SPI6 in the Krong No District of Dak Nong Province, Vietnam

\begin{tabular}{llll}
\hline SPI6 $^{\text {a }}$ & Lak (1981-2010) & Duc Xuyen (1981-2016) & Dak Nong (1981-2013) \\
\hline Total events & 355 & 427 & 391 \\
Moderate drought $(-1$ to -1.49$)$ & 37 & 49 & 21 \\
Severe drought $(-1.5$ to -1.99$)$ & 16 & 10 & 15 \\
Extreme drought $(\leq-2)$ & 4 & 13 & 9 \\
Total drought events $(\leq-1)$ & 57 & 72 & 45 \\
Drought frequency & 0.16 & 0.17 & 0.12 \\
\hline
\end{tabular}

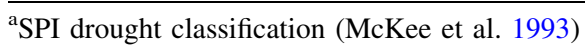


affects the lives of households. Drought leads to crop failure and lack of water, making the people's lives more difficult in the next period.

\subsection{Livelihood Vulnerability in the Krong No District}

Figure 4a presents the diagram for the seven major components of LVI for the Krong No District. There are two imbalance aspects-Water (0.774) and Livelihood strategies (0.661). These aspects are the two main factors that increase the vulnerability of the district. The Sociodemographic aspect of Krong No is quite good. Our surveys show that the sociodemographic profile of most households indicates a relatively low vulnerability $(0.168)$. The burden imposed by a large-sized family, as well as a femaleheaded household, has significantly decreased since 25 years ago when the family planning program was successfully implemented in rural areas. In the last 10 years, small-sized families and the number of children going to

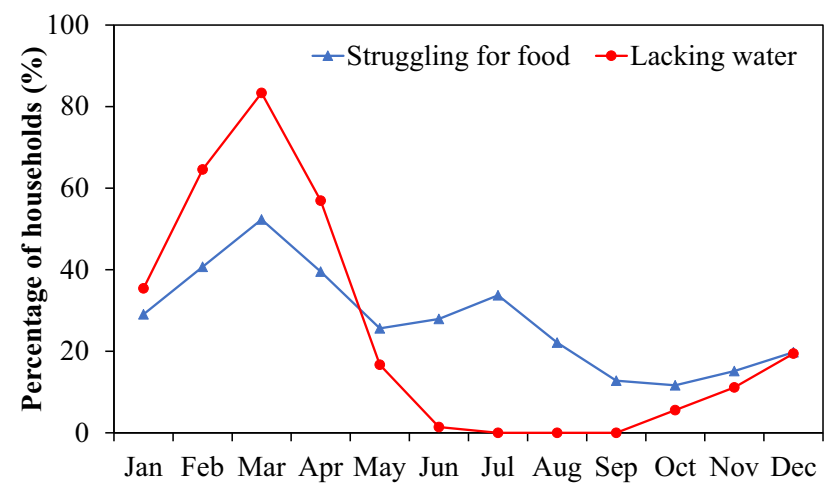

Fig. 3 Percentage of households struggling for food and lacking water in the Krong No District in Dak Nong Province, Vietnam school have increased, which contribute to mitigate the vulnerability of the district.

Water source is the dreadful issue in the district. Our survey reveals that approximately $70 \%$ of households lack sufficient water for domestic use and irrigation in the dry season. In three out of the five surveyed communities, $100 \%$ of households are dependent on natural water sources and lack access to a central water supply system (W1 and W2, Table 2). Once a dry season is prolonged, the district becomes one of the most vulnerable places in the country. The other main reasons are that households significantly depend on farming and rural poverty has not been completely eliminated. In addition to water, the second prominent problem is the livelihood strategy of the households. Households in Krong No have poor, undiversified livelihood strategies, and they are considered a vulnerable community even when droughts do not occur. This is attributed to the fact that the livelihood of more than $80 \%$ of households depends entirely on farming and smallscale livestock production. Most members of these households do not have a job that generates a stable salary; when a drought happens, it leads to severe crop failure and a great impact on the livelihood of households, because they have no other source of income to compensate for the loss. As a result, there is no money to cover living expenses and this leads to food and water shortages, disease, and poverty year after year.

The VI-IPCC index also indicates that the vulnerability of the district is at a medium level $(-0.096)$ based on the vulnerability scale of -1 to +1 . The VI-IPCC result is presented in a spider chart (Fig. 4a) and in different format using three contributing factors (calculated in Eq. 4), aggregated from the seven major components in Fig. 4a, and displayed in a pyramid chart (Fig. 4b). In general, the adaptive capacity of households just surpasses the average
Fig. 4 Vulnerability spider diagram of the livelihood vulnerability index (LVI) major components (a) and Vulnerability IndexIntergovernmental Panel on Climate Change (VI-IPCC) major components pyramid diagram (b) for the Krong No District in Dak Nong Province, Vietnam. Note:

SDP $=$ Sociodemographic profile; $\mathrm{LS}=$ Livelihood strategy; F = Food; W = Water; $\mathrm{H}=$ Health; $\mathrm{SN}=$ Social networks; D = Drought; AC = Adaptive capacity; $\mathrm{E}=$ Exposure; $\mathrm{S}=$ Sensitivity

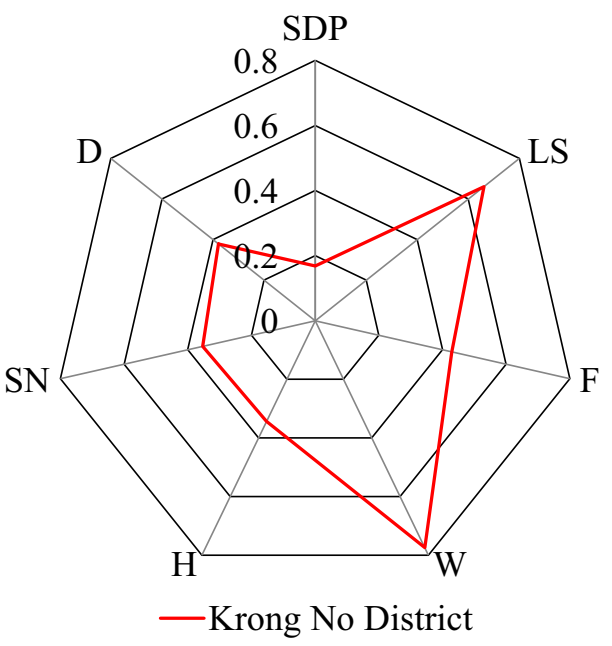

(a) LVI major components

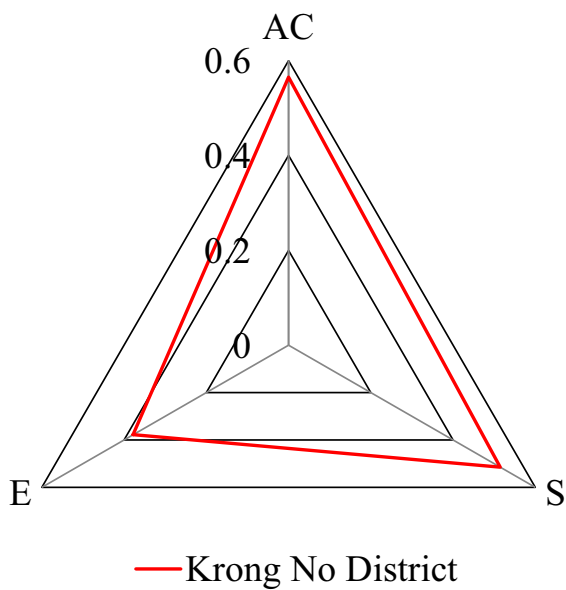

(b) VI-IPCC major components 
(approximately 0.6), but is not strong enough to respond to the impacts of drought. Sensitivity shows that the living standard of the community is still low and needs more support from the government. The VI-IPCC indicates that both adaptive capacity (AC) and sensitivity (S) should be taken into consideration during drought mitigation efforts in which sensitivity (water, food, and health) should be prioritized. The result suggested that household adaptive capacity also needs to be addressed directly, because community capacity is the key to solving economic, social, and environmental problems. Oo et al. (2018), in addressing similar issues in Myanmar, stated that lack of households adaptive capacity is a main cause of high vulnerability to the impacts of climate change and disasters. Studies in West Africa and in the Himalayas indicated that knowledge (Obayelu et al. 2014) and income (Aryal et al. 2014) are key factors in determining household adaptive capacity and reducing household vulnerability. When knowledge and economy combine to make a community strong, that society will be able to improve its quality of life on their own initiative. Once drought takes place and lasts, strengthened social institution will have enough vitality to survive, mitigate, and recover from drought damages.

\subsection{Livelihood Vulnerability of Five Communities}

Vulnerability of the five communities in the Krong No District in decreasing order is: Quang Phu, Nam N'dir, Dak Nang, Duc Xuyen, and Dak D'ro (Table 3). Quang Phu $(\mathrm{LVI}=0.510)$ needs special attention, followed by Nam $\mathrm{N}^{\prime} \operatorname{dir}(\mathrm{LVI}=0.486)$. Table 3 indicates in detail the vulnerability aspects of each community. Through this table, it is easy to see what specific issues need to be addressed for each community. This study presents two aspects that need special attention for all five communes-water availability and diversified livelihood strategies for the residents. Although on issues of water sources, all five communes have serious concerns, the Dak Nang, Quang Phu and Nam N'dir communities are the three most vulnerable areas in the water component with very high LVI values of 0.884 , 0.855 , and 0.839 , respectively (Table 3 ). The water issue seems to be extremely critical, especially when the prolonged dry season leads to droughts that severely affect the lives of the local people. In terms of livelihood strategies, the table also shows that all five communities need attention because their vulnerability is relatively high, and Quang Phu and Dak Nang are considered as the two most vulnerable communities. Finally, the social network component (SN) shows that Quang Phu and Nam Nam N'dir are two communities needing more attention because adequate communication facilities and support policies are not widely present in either community. Quang Phu and
Nam N'dir also need more food and health support than do others. Therefore, it is necessary to have appropriate policies for these two communities so that once support policies are proposed and implemented, those initiatives will be effective. For Quang Phu, the order of priority is for support policies that sustain people's livelihoods and reduce the impact of the natural element-drought. The priority sequence is as follows: water $>$ livelihood strategies $>$ food $>$ health $>$ social networks $>$ sociodemographic profile. For Nam N'dir, priority is proposed as follows: water $>$ livelihood strategies $>$ food $>$ social networks $>$ health $>$ sociodemographic profile.

Figure 5 indicates that livelihood vulnerability in the five communities mainly comes from two contributing factors-adaptive capacity (AC) and sensitivity (S). In terms of adaptive capacity, VI-IPCC considers household sociodemographic profile, livelihood strategies, and social networks; and in terms of sensitivity, it considers water, food, and health component. Figure 5 also clearly shows differences in these two factors, and between two communities (Quang Phu and Nam N'dir) and the other communities. The communities are ranked in order of capacity

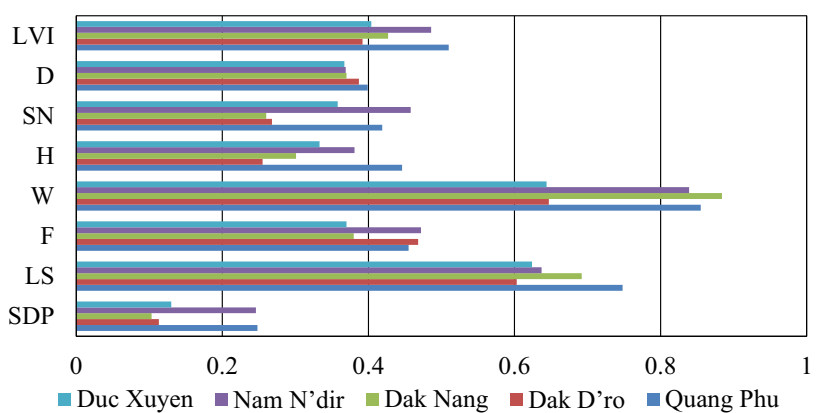

(a) LVI major components

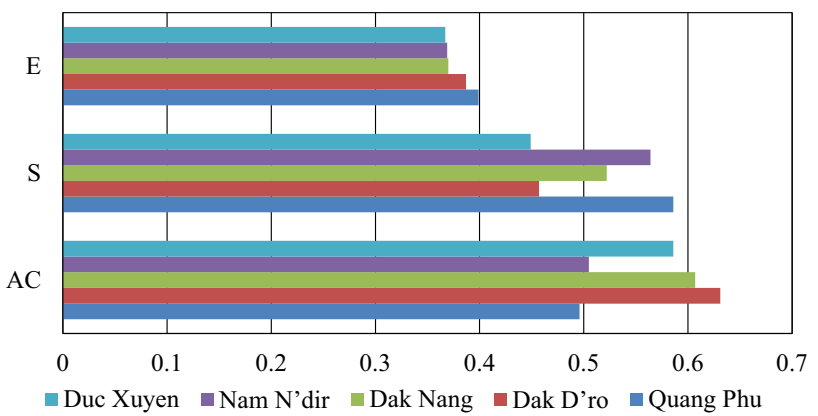

(b) VI-IPCC major components

Fig. 5 Contributing factors of livelihood vulnerability index (LVI) major components (a) and Vulnerability Index-Intergovernmental Panel on Climate Change (VI-IPCC) major components (b) for the five communities in the Krong No District in Dak Nong Province, Vietnam. Note: SDP = Sociodemographic profile; $\mathrm{LS}=$ Livelihood strategy; $\mathrm{F}=$ Food; $\mathrm{W}=$ Water $; \mathrm{H}=$ Health; $\mathrm{SN}=$ Social networks; $\mathrm{D}=$ Drought $; \quad \mathrm{AC}=$ Adaptive $\quad$ capacity $; \quad \mathrm{E}=$ Exposure; $\mathrm{S}=$ Sensitivity 
from low to high: Quang Phu $>$ Nam N'dir $>$ Duc Xuyen $>$ Dak Nang $>$ Dak D'ro. In general, Dak D'ro has the best adaptive capacity in comparison with the other communities, partly because of its location nearing the district center, whereas Quang Phu is the farthest distance from local site to district administrative support center. Finally, the impacts of drought are indirectly shown by the components of the sensitivity factor. The order of sensitivity from high to low are: Quang Phu $>$ Nam N'dir $>$ Dak Nang $>$ Dak D'ro $>$ Duc Xuyen. Again, Quang Phu and Nam N'dir are the two communities with a higher vulnerability factor than the other communities. In summary, all results show that Quang Phu and Nam N'Dir are the two vulnerability hotspots of Krong No District.

\subsection{Discussion}

The results of this study indicate that water availability and effective livelihood strategies are the most important factors in determining livelihood vulnerability for the five surveyed communities in Krong No District. According to the survey results, most households in the study area mainly depend on natural sources of water because of the absence of a community water supply system and almost universally their livelihoods lack diversity because they rely only on agriculture for income. This dependence produces high vulnerability to the impacts of climate change and climate variability, especially water shortage in the dry season (Hahn et al. 2009). In addition, the water problem is attributed to a high reliance of farming on water (Pandey et al. 2015; Panthi et al. 2016). Water problems for the study area may increase, because the streamflow is predicted to significantly decrease in the future, especially in the dry season (Sam et al. 2018). Under the impacts of drought, the study area must find alternative water resources, such as wells, ponds, or rainwater harvesting. Moreover, new water management practices, such as drip irrigation, irrigation supplements, and the adoption of stress-tolerant crop varieties, need to be introduced to solve current and future water deficit problems.

Because the main livelihood system of the five surveyed communities in the district is farming, the main income of these communities is more likely to be affected adversely by droughts. The low values of the livelihood diversification indices (LS1 and LS3) of these communities are a reason for the high vulnerability of existing livelihood strategies. This finding is consistent with the insights of Aryal et al. (2014), Oo et al. (2018), and Antwi-Agyei et al. (2013), who pointed out that a household is judged less vulnerable if there are more than two income sources in a family to improve livelihood diversification. In the face of drought impacts, livelihood stability for households in the five communities is emphasized, and livelihood diversification in terms of a mixture of farming and nonfarming activities is recommended to reduce vulnerability from drought impacts on households.

In general, the LVI and VI-IPCC indices are effective in determining household vulnerability for the five study areas. By using these indices, the vulnerability level between different sites within a study area can be compared. However, the same two indices may not be readily compared with other investigations in more distant regions because of different subcomponents (indicators) and contexts. Indeed, Hahn et al. (2009) suggested that selection of subcomponents significantly affects the assessment result of household livelihood vulnerability to climate change and natural hazards. Panthi et al. (2016) also contend that local environment affects the frame and design of the subcomponents. Selection of appropriate subcomponents is a challenge in the use of vulnerability indices. As this study demonstrates, extensive literature review, expert consultation, and stakeholder consultation are recommended for designing subcomponents of the vulnerability indices (LVI and VI-IPCC).

\section{Conclusion}

In this study, livelihood vulnerability of farmers in Krong No District, Dak Nong Province on the Central Highlands of Vietnam was investigated by using two vulnerability indices: LVI and VI-IPCC. The main findings can be summarized as follows: (1) results of LVI and VI-IPCC indicated that the Krong No District is at a medium level of livelihood vulnerability under the impacts of drought (0.444 and - 0.096); (2) considering the vulnerability of five surveyed communities, the overall LVI and VI-IPCC values from the major components pointed out that households of the Quang Phu community are the most vulnerable to drought, with indices of 0.510 and -0.057 , followed by Nam N'dir, Dak Nang, Duc Xuyen, and Dak D'ro communities; and (3) this study also indicated that water (sensitivity) and livelihood strategies (adaptive capacity) are two major causes of high vulnerability to the impacts of drought for the district and all surveyed communities. Therefore, this study recommends increasing investment in water management practices and livelihood diversification. In future research, vulnerability under some policy interventions will be investigated to see the effectiveness of planned activities in reducing livelihood vulnerability of communities of the area.

Acknowledgements This research is funded by the Vietnam National Foundation for Science and Technology Development (NAFOSTED) under Grant Number 105.06-2013.09. 
Open Access This article is distributed under the terms of the Creative Commons Attribution 4.0 International License (http://crea tivecommons.org/licenses/by/4.0/), which permits unrestricted use, distribution, and reproduction in any medium, provided you give appropriate credit to the original author(s) and the source, provide a link to the Creative Commons license, and indicate if changes were made.

\section{References}

Addisu Legese, S., O.A. Olutayo, H. Sulaiman, and P. Rao. 2016. Assessing climate change impacts in the Lake Tana Sub-Basin, Ethiopia using livelihood vulnerability approach. Journal of Earth Science \& Climatic Change 7(9): Article 368.

Adu, D.T., J.K.M. Kuwornu, H. Anim-Somuah, and N. Sasaki. 2018. Application of livelihood vulnerability index in assessing smallholder maize farming households' vulnerability to climate change in Brong-Ahafo region of Ghana. Kasetsart Journal of Social Sciences 39(1): 22-32.

Antwi-Agyei, P., A.J. Dougill, E.D.G. Fraser, and L.C. Stringer. 2013. Characterising the nature of household vulnerability to climate variability: Empirical evidence from two regions of Ghana. Environment, Development and Sustainability 15(4): 903-926.

Aryal, S., G. Cockfield, and T.N. Maraseni. 2014. Vulnerability of Himalayan transhumant communities to climate change. $\mathrm{Cli}$ matic Change 125(2): 193-208.

Dak Nong Statistical Office. 2015. Statistical yearbook of Dak Nong 2014. Dak Nong, Vietnam: Young Publishing House. https:// daknong.gov.vn/documents/304992/0/niengiamthongke2014. pdf/a22636a5-fc16-4e3d-b512-556cc74e6b30. Accessed 10 Aug 2018.

Eckstein, D., V. Kunzel, and L. Schafer. 2017. Global climate risk index 2018: Who suffers most from extreme weather events? Weather related loss events in 2016 and 1997 to 2016. Berlin: Germanwatch. https://germanwatch.org/sites/germanwatch.org/ files/publication/20432.pdf. Accessed 15 Oct 2018.

FAO (Food and Agriculture Organization of the United Nations). 2016. "El Niño" event in Viet Nam: Agriculture, food security and livelihood needs assessment in response to drought and salt water intrusion. Ha Noi: FAO. http://www.fao.org/fileadmin/ user_upload/emergencies/docs/a-i6020e.pdf. Accessed 15 Oct 2018.

Hahn, M.B., A.M. Riederer, and S.O. Foster. 2009. The livelihood vulnerability index: A pragmatic approach to assessing risks from climate variability and change-A case study in Mozambique. Global Environmental Change 19(1): 74-88.

IMHEN (Institute of Meteorology, Hydrology and Environment) and UNDP (United Nations Development Programme). 2015. Viet Nam special report on managing the risks of extreme events and disasters to advance climate change adaptation: Summary for policy makers. Hanoi, Vietnam: Natural Resources and Environment Publishing House. http://www.vn.undp.org/content/viet nam/en/home/library/environment_climate/viet_nam_special_ report_on_managing_the_risks_of_extreme_events_and_disas ters.html. Accessed 15 Oct 2018.

IPCC (Intergovernmental Panel on Climate Change). 2001. Climate change 2001: Impacts, adaptation, and vulnerability, ed. J.J. McCarthy, O.F. Canziani, N.A. Leary, D.J. Dokken, and K.S. White. Cambridge, UK: Cambridge University Press.

IPCC (Intergovernmental Panel on Climate Change). 2007. Summary for policymakers. In Climate change 2007: Impacts, adaptation and vulnerability, ed. M.L. Parry, O.F. Canziani, J.P. Palutikof, P.J. van der Linden, and C.E. Hanson, 7-22. Cambridge, UK: Cambridge University Press.
IPCC (Intergovernmental Panel on Climate Change). 2013a. Climate change 2013: The physical science basis. Contribution of working group I to the fifth assessment report of Intergovernmental Panel on Climate Change, ed. T.F. Stocker, D. Qin, G.K. Plattner, M. Tignor, S.K. Allen, J. Boschung, A. Nauels, Y. Xia et al. Cambridge, UK: Cambridge University Press.

IPCC (Intergovernmental Panel on Climate Change). 2013b. Summary for policymakers. In Climate change 2013: The physical science basis. Contribution of working group I to the fifth assessment report of Intergovernmental Panel on Climate Change, ed. T.F. Stocker, D. Qin, G.-K. Plattner, M. Tignor, S.K. Allen, J. Boschung, A. Nauels, Y. Xia et al., 1-30. Cambridge, UK: Cambridge University Press.

Keesstra, S.D. 2007. Impact of natural reforestation on floodplain sedimentation in the Dragonja basin, SW Slovenia. Earth Surface Processes and Landforms 32(1): 49-65.

McKee, T.B., N.J. Doesken, and J. Kleist. 1993. The relationship of drought frequency and duration to time scales. In Proceedings of the 8th conference on applied climatology, 17-22 January 1993, Anaheim, CA, USA. https://climate.colostate.edu/pdfs/relation shipofdroughtfrequency.pdf. Accessed 10 Jan 2017.

Mohmmed, A., K. Zhang, M. Kabenge, S. Keesstra, A. Cerdà, M. Reuben, M.M.A. Elbashier, T. Dalson, and A.A.S. Ali. 2018. Analysis of drought and vulnerability in the North Darfur region of Sudan. Land Degradation \& Development 29(12): $4424-4438$.

Obayelu, O.A., A.O. Adepoju, and T. Idowu. 2014. Factors influencing farmers' choices of adaptation to climate change in Ekiti State, Nigeria. Journal of Agriculture and Environment for International Development 108(1): 3-16.

Oo, A.T., G.V. Huylenbroeck, and S. Speelman. 2018. Assessment of climate change vulnerability of farm households in Pyapon District, a delta region in Myanmar. International Journal of Disaster Risk Reduction 28: 10-21.

Pandey, R., and S. Jha. 2012. Climate vulnerability index-measure of climate change vulnerability to communities: A case of rural Lower Himalaya, India. Mitigation and Adaptation Strategies for Global Change 17(5): 487-506.

Pandey, R., S. Kala, and V.P. Pandey. 2015. Assessing climate change vulnerability of water at household level. Mitigation and Adaptation Strategies for Global Change 20(8): 1471-1485.

Panthi, J., S. Aryal, P. Dahal, P. Bhandari, N.Y. Krakauer, and V.P. Pandey. 2016. Livelihood vulnerability approach to assessing climate change impacts on mixed agro-livestock smallholders around the Gandaki River Basin in Nepal. Regional Environmental Change 16(4): 1121-1132.

Salik, K.M., S. Jahangir, W.Z. Zahdi, and S. Hasson. 2015. Climate change vulnerability and adaptation options for the coastal communities of Pakistan. Ocean \& Coastal Management 112: $61-73$.

Sam, T.T., D.N. Khoi, N.T.T. Thao, P.T.T. Nhi, N.T. Quan, N.X. Hoan, and V.T. Nguyen. 2018. Impact of climate change on meteorological, hydrological and agricultural droughts in the Lower Mekong River Basin: A case study of the Srepok Basin, Vietnam. Water and Environment Journal 149(1): 107-119.

Shah, K.U., H.B. Dulal, C. Johnson, and A. Baptiste. 2013. Understanding livelihood vulnerability to climate change: Applying the livelihood vulnerability index in Trinidad and Tobago. Geoforum 47: 125-137.

Spinoni, J., G. Naumann, H. Carrao, P. Barbosa, and J. Vogt. 2014. World drought frequency, duration, and severity for 1951-2010. International Journal of Climatology 34(8): 2792-2804.

Thilakarathne, M., and V. Sridhar. 2017. Characterization of future drought conditions in the Lower Mekong River Basin. Weather and Climate Extremes 17: 47-58. 
UNDP (United Nations Development Programme). 2007. Human development report 2007/2008. Fighting climate change: Human solidarity in a divided world. New York, USA: UNDP.

UNDP (United Nations Development Programme). 2016. Viet Nam drought and saltwater intrusion: Transitioning from emergency to recovery. Vietnam: UNDP.
Williams, P.A., O. Crespo, and M. Abu. 2018. Assessing vulnerability of horticultural smallholders' to climate variability in Ghana: Applying the livelihood vulnerability approach. Environment, Development and Sustainability. https://doi.org/10.1007/s10668018-0292-y. 